\title{
Fate of Zearalenone, Ochratoxin A and Aflatoxin B1 Present in Wheat Flour Used for Bread Production
}

\author{
Juliane Elisa Welke (I), Flávio Fonseca Veras (I), Bruna Dachery (I), \\ Emili Keller Bol (I), Débora Senger (I) \\ (I) ICTA/UFRGS - Instituto de Ciência e Tecnologia de Alimentos/ UFRGS (Av. Bento \\ Gonçalves n. 9500, Porto Alegre - RS, Brasil)
}

\section{Resumo}

Zearalenone (ZEA), ochratoxin A (OTA) and aflatoxin B1 (AFB1) are mycotoxins that may occur in cereals, such as wheat, and thus may be found in cereal by-products. Bread is considerable a component of every day diet not only in Brazil, but also in many countries. Mycotoxins have different negative effects to health. ZEA, OTA and AFB1 have been mainly associated with hyperestrogenism effects, nephrotoxicity and hepatotoxicity, respectively. Brazilian legislation establishes maximum limits for the presence of six mycotoxins in various foods, including limits for ZEA $(200 \mu \mathrm{g} / \mathrm{kg})$ in wheat flour and bakery products with application until December of 2015. Furthermore, maximum limits were established for aflatoxin $(5 \mu \mathrm{g} / \mathrm{kg})$ and OTA $(10 \mu \mathrm{g} / \mathrm{kg})$ in cereals and cereal products. The objective of this work is to evaluate the processing effects of bread on ZEA, OTA and AFB1 levels. The processing effects of bread on mycotoxins levels were evaluated considering that the wheat flour was contaminated with the maximum limit established by Brazilian legislation for each mycotoxin. For the preparation of bread, $100 \mathrm{~g}$ of wheat flour was taken and the following ingredients were added: dry Saccharomyces cerevisiae yeast $(1 \mathrm{~g})$, saccharose $(1.7 \mathrm{~g})$, vegetable oil $(1.5 \mathrm{~g})$, salt $(0.7 \mathrm{~g})$ and water $(50 \mathrm{ml})$. The dough was kept in a fermentation chamber with controlled temperature to ferment at $30^{\circ} \mathrm{C}$ for 50 minutes. The dough was then divided into pieces of $70 \mathrm{~g}$ each and molded by hand. The dough pieces kept for more $45 \mathrm{~min}$ in fermentation chamber at the same

\footnotetext{
Referência:

Juliane Elisa Welke, Flávio Fonseca Veras, Bruna Dachery, Emili Keller Bol, Débora Senger.Fate of Zearalenone, Ochratoxin A and Aflatoxin B1 Present in Wheat Flour Used for Bread Production. In: Anais do 12o Congresso Latinoamericano de Microbiologia e Higiene de Alimentos - MICROAL 2014 [= Blucher Food Science Proceedings, num.1, vol.1]. São Paulo: Editora Blucher, 2014. DOI 10.5151/foodsci-microal-096
} 
temperature $\left(30^{\circ} \mathrm{C}\right)$ before baking at $220^{\circ} \mathrm{C}$. Mycotoxins were determined using thin-layer chromatography with charge coupled device detector. The reduction of mycotoxins levels in dough in comparison to the flour occurred due to dilution effects. After ingredients added to the flour, the mycotoxins levels were reduced around 36 times. Flour corresponds to 65 of the total quantity of ingredients used in bread production. Considering the reduction of mycotoxins after baking, AFB1 proved to be the most thermoresistent mycotoxin with no significant reduction. OTA and ZEA showed the higher reduction rates after baking at $220^{\circ} \mathrm{C}$, achieving 80 and $98 \%$ of reduction, respectively. The extent of reduction in mycotoxins levels depends on processing conditions, amount of flour used in formulation and the stability of the toxin.

Palavras-Chave: mycotoxin, processing effect, baking Agência de Fomento: FAPERGS; CAPES 